pages by Dr. Chree and others, the nuclei, owing to their large numbers, have possibly a greater effect than the visible particles.

The effect of impure air on visibility has been investigated by the Committee and two photometric methods of measuring the obstructive power of polluted air have been perfected. Approximate proportionality has been established between the light obstruction and the quantity of pollution present as measured by the filter and jet methods. But the Committee finds that "some factor other than the simple obstruction of area of the light source is responsible for the loss of light in passing through the air." It might elucidate this point and help to a fuller examination of the whole problem of contaminated air if observations of the total condensation nuclei were taken after the manner of Aitken. It would be unsafe to assume a proportionality between the visible dust and the nuclei. Many sources of large particles may yield few nuclei and certain rich sources of nuclei, Bunsen flames, for example, may be expected to give few large particles. In this connexion the writer noticed some months ago that during a three weeks' gas-strike in Dublin, the number of large ions was much below the normal. Irregular variations are so common that it may be difficult to decide if the reduction is a genuine effect unless a further opportunity for investigation - otherwise undesirable - should present itself. The Committee has already achieved such a high level of success in the development of methods of observation and in the perfecting of instruments, that if it can be induced to undertake the observation of condensation nuclei, those of us who are interested in atmospheric nucleation may expect to see instruments developed of a far higher standard of efficiency than those available at present.

It should be stated that the automatic dust-recorder and the jet dust counter are now in use in many countries. They are available for purchase, and full instructions for their operation can be obtained. There is no doubt that they will prove of great value in dealing with a multitude of problems relating to impure air.

The chief evil of a polluted atmosphere is not the æsthetic horror of the smoke canopy, the grimy buildings and the stunted vegetation. It is not even the inspiration of dirty air-and we learn from this report that in the course of twenty-four hours of a heavy smoke fog, the dweller in London breathes in $500,000,000,000$ particles of suspended matter. The real crime is the cutting off of sunlight. We have yet to learn in detail how the impure atmosphere of cities operates to abstract those elements in sunlight which appear to be necessary for health, and we have yet to test the possibility of minimising the evil. Meanwhile it is to be hoped that the Committee on Atmospheric Pollution may be enabled to extend and develop the fruitful work it has undertaken.

J. J. Nolan.

\title{
The "Terrella."
}

THE name "Terrella" appears to have been first used towards the end of the sixteenth century to describe a sphere of loadstone used as a miniature replica of the earth for the study of terrestrial magnetism. Seventeenth century writers mention terrellas fairly frequently but there are not many descriptions of particular specimens, and although considerable numbers must have been in use during the seventeenth century, very few indeed appear to have survived. Rounded loadstones had been used from very early days. Peregrinus, for example, in the thirteenth century, mentions a method of making them and of finding the poles, but he does not give any particular scientific use to which they could be turned.

It was not until Gilbert of Colchester, in the prosecution of his studies in magnetism, etc., found that a miniature of the globe constructed of a suitable piece of magnetic ore would be of great assistance in his researches, that the rounded loadstone of earlier investigators was developed into a more or less scientific instrument. Dr. Gilbert, early in his great work "De Magnete" (I600), gives details for the manufacture of an instrument "Called by us a Terrella," this being described as a " physical Corpuscle imbued with many virtues by means of which many abstruse and neglected truths in philosophy burried in piteous darkness may more readily become known to men."

Many chapters of "De Magnete " are wholly devoted to details as to manufacture, graduation and the experimental use to be made of the finished article. Chapter XVII., Book II., giving details of methods of arming to "increase the virtue" of the instrument, is of special interest in connexion with the three specimens to be described. In order to show the opinion of his successors the following extract from Sir Kenelm Digby's (I644) "Two Treatises, on the Nature of Bodies: and, the Nature of the Man's Soule is looked into " will be of interest-

"But to come to some experimentall proofes and Obseruations on the loadstone by which it will appeare that these causes are well esteemed and applyed, we must be beholdin to that admirable searcher of the nature of the loadstone, Dr. Gilbert; by means of whom and of Dr. Haruey, our nation may claim euen in this latter age as deserued a crowne for solide Philosophicall learning as for many ages together it hath done formerly for acute and subtile Speculations in Diuinity. But before I fall to particulars, I thinke it worth warning my Reader, how this great man arriued to discover so much of Magneticall Philo sophy; that he, likewise, if he be desirous to search into nature, may, by imitation, aduance his thoughts and knowledge that way. In short, then, all the knowledge he gott of this subject was by forming a little loadstone into the shape of the Earth. By which means he compasses a wonderful designe which was to make the whole globe of the earth maniable; for he found the properties of the whole earth in that little body; which he therefore called 'Terrella' or 'Little Earth'; and which he could manage and trye experiences vpon att his will. And, in like manner any man that hath an ayme to aduance much in naturall sciences, must endeavour to draw the matter he inquireth of, into some such modell, or some kinde of manageable methode; which he may turne and winde as he pleaseth. And then lett him be sure, if he hath a competent vnderstanding, that he will not misse of his marke."

$$
\text { NO. } 2872 \text {, vOL. I I } 4]
$$


The following references tc definite instruments may be found in seventeenth-century records.

r. John Evelyn, July 1655 , in his diary mentions a "pretty terrella with the circles and showing the magnetic deviations."

2. Pepys under October 2, I662, states he " received a letter from Mr. Barlow with a Terrella."

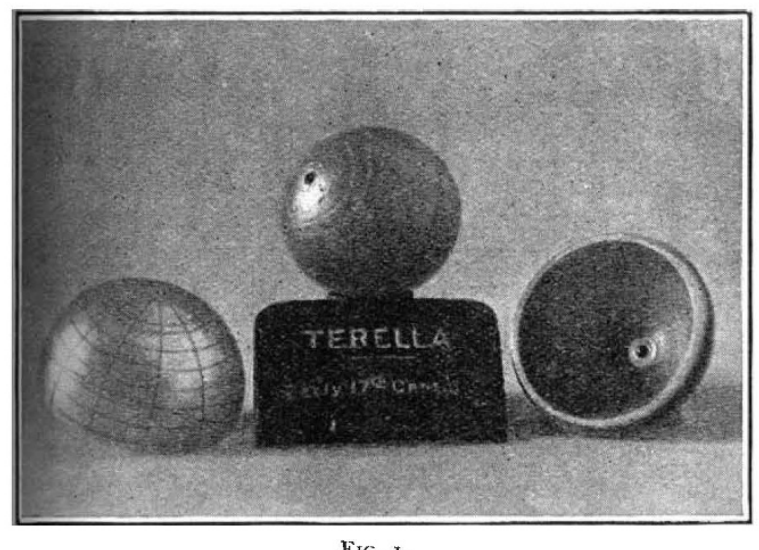

3. A terrella, $4 \frac{1}{2}$ in. in diameter, was presented in 1662 by King Charles II. to the Royal Society.

4. In Grew's catalogue and description of the rarities belonging to the Royal Society, and preserved at Gresham College (London, I68I, p. 364), is mentioned a terrella contrived by Sir Christopher Wren with one half immersed in the centre of a plane horizontal table.

5. In Sir John Pettus's "Fleta Minor," London I683, in the "Dictionary of Metallick Words" at the end, under the word "Loadstone" occurs the following paragraph :

"Another piece of curiosity I saw in the hands of Sir William Persal (since deceased also), viz. a Terrella or Loadstone, of little more than 6 in. diameter, turned into a Globular form, and all the imaginary lines of our Terrestrial Globe, exactly drawn upon it, viz. the Arctick and Antarctick circles, the two Tropics, the two Colures, the Zodiac and Meridian : and these lines, and the several countryes, artificially painted on it."

So far as can be ascertained, only three instruments which can be strictly included under the term "Terrella" can now be traced, and as all three are at present in the Admiralty Compass Department Museum at Ditton Park, a brief description of their characteristics and the little that is known of their history is possible.

r. Compass Department Terrella.-This is by far the most finished and efficient instrument of the three; in fact, it is the only one which might be termed a scientific instrument, and which carried out Gilbert's practice to the utmost. Its history prior to the early years of the nineteenth century is unknown, but then it hung as a curiosity in the shop window of the wellknown compass makers, Messrs. Grant Preston, Barr Street, London, and is mentioned as being seen there in 1844 . It came into the personal possession of Captain W. Mayes, R.N. (Superintendent of Compass Department), in 1887 , and has remained in the Museum since that date.

General Description.-The instrument (Fig. I) consists of three parts: (a) the terrella of highly magnetic ore $I^{\prime} 7$ inch in diameter, $(b)$ and $(c)$ two brass hemispheres which when screwed together form the arming and casing. Great circles and parallels of latitude are engraved on both the sphere and its case, and a very special feature of the latter is the iron cap ( $\frac{1}{3}$ inch in diameter) let into the north pole forming one piece with the projection inside; the efficiency of this arrangement in collecting the lines of force is obvious from the increased lift given below, and the results would probably be better if the pin and depression in the north pole of the terrella were not considerably worn and the fit therefore loose, and also if suitably designed weights were used. The small pin at the south pole appears to be simply intended to hold the sphere firmly in place. The terrella itself weighs $6 \frac{3}{8} \mathrm{oz}$., and unarmed lifts $1 \frac{3}{4} \mathrm{oz}$. ; with the case in place, however, this lift is increased to $9 \frac{3}{8} \mathrm{oz}$.

2. Royal Society Terrella (R.S. No. 80).-This is a roughly turned sphere of loadstone $4 \frac{3}{8}$ in. in diameter, and marked witk a cross at each pole. No method of arming is provided. It weighs $7 \mathrm{lb} .2 \frac{1}{2} \mathrm{oz}$, and has a lift of $6 \mathrm{oz}$.

3. Royal Society Terrella, 3 in.-Sphere of loadstont (Fig. 2) slightly flattened at the south pole. Faint red markings show that meridians and equator have been roughly drawn. For " arming"-the sphere is loosely held between two iron cups joined by a silver bridge. It weighs $2 \mathrm{lb}$. $\mathrm{I}_{2}^{\frac{1}{2}} \mathrm{O}^{7}$.., and lifts when armed, $3 \mathrm{oz}$.

The summary of all the available information past and present on particular instruments is remarkably meagre, and, when it is considered that many must have been in use during the seventeenth century, it is surprising that more specimens have not survived in museums and private collections; it is possible that the publication of this short article will result in bringing to light a few more of these interesting instruments.

Dr. Gilbert's work evidently aroused the interest of many of the great investigators of his time, and there appears to have arisen a demand for " armed" loadstones as scientific curiosities which fetched high

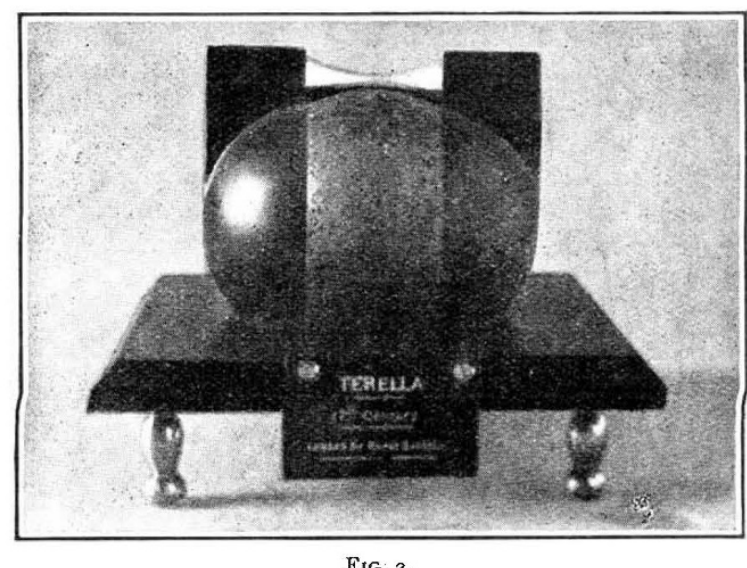

prices. Galileo especially brought their manufacture to a high pitch of perfection if the records of his achievements can be credited ; his loadstones were not, however, terrellas, as is clear from the very interesting paper entitled "Galileo and Magnetism, a Study in Loadstones," by J. J. Fahie, published in the Journal of the Institution of Electrical Engineers, vol. 56, p. 246 .
F. C.-O.

NO. 2872 , VOL. I I 4 ] 